Jurnal SEMAR Vol. 8 No. 2, 2019 hal. $10-16$

ISSN: 2302-3937 | Copyright (C) LPPM Universitas Sebelas Maret Homepage: https://jurnal.uns.ac.id/jurnal-semar

\title{
Pemanfaatan Tanaman Daun Gatal di Arso XIV
}

\author{
Eva Susanty Simaremare* | Rani Dewi Pratiwi | Elsye Gunawan \\ Farmasi, Jurusan Farmasi, Fakultas Matematika dan Ilmu Pengetahuan Alam Universitas Cenderawasih
}

\begin{abstract}
Abstrak
Kampung Wulukubun Arso XIV, Distrik Skanto Kabupaten Kerom banyak ditumbuhi daun gatal yang bermanfaat sebagai obat tradisional sebagai antinyeri, mengurangi rasa capek, dan mengurangi pegal-pegal. Daun gatal banyak terdapat di kampung tapi sering sekali hanya dibiarkan kering, layu, mati, bahkan dibuang. Padahal nilai dari daun ini sangat besar jika dikembangkan tidak hanya lembaran daun gatal teapi sebagai produk farmasi. Tujuan dari kegiatan ini adalah untuk melaksanakan program pengabdian untuk memberdayakan, menguatkan partisipasi masyarakat dalam swamedikasi dan optimalisasi potensi tanaman obat daun gatal dan peningkatan kesehatan dan ekonomi kampung Wulukubun Arso XIV dalam bentuk sedian topikal salep daun gatal. Kegiatan ini dilaksanakan dengan metode persiapan, menjalin kerjasama dengan mitra, instansi terkait, kegiatan hari $\mathrm{H}$ di kampung, evaluasi, laporan, dan publikasi. Hasil yang diperoleh dari kegiatan ini adalah $7,4 \%$ peserta pernah mengikuti kegiatan yang sama. Sebanyak $88,9 \%$ peserta memperoleh manfaat dari kegiatan ini dan 70,4\% berkomitmen akan membantu orang lain dalam menyebarluaskan informasi penting yang mereka dapat pada waktu kegiatan ini.
\end{abstract}

Kata Kunci: Daun gatal, simplisia, swamedikasi, salep, Arso XIV

\section{Pendahuluan}

Kampung Walukubun, Arso XIV berada di Distrik Skanto Kabupaten Kerom yang berjarak kira-kira $54,3 \mathrm{~km}$ dari Uncen yang ditempuh kurang lebih 2 jam. Hutan di distrik ini banyak ditumbuhi oleh tanaman daun gatal yang sebagian masyarakat digunakan sebagai tanaman obat antinyeri topikal. Akan tetapi di sisi lain banyak juga masyarakat pendatang tidak mengenal tanaman ini. Sehingga tanaman ini tidak dipelihara atau dirawat dengan baik oleh masyarakat karena masyarakat tidak memahami dengan baik penggunaan tanaman ini secara etnofarmakologi.

Daun gatal merupakan tanaman dimana bentuk daun bergerigi dan memiliki bulu-bulu halus di sepanjang daun dan batang (Gambar 1). Tumbuhan ini banyak dimanfaatkan oleh masyarakat secara etnofarmakologi termasuk di distrik Depapre sebagai obat antinyeri/ analgesik secara tradisional. Khususnya masyarakat Arso XIV dan kota-kota lain di menggunakan tanaman ini untuk mengatasi keluhan kesehatan sebagai antinyeri seperti rasa sakit, kaku/ pegal, sakit perut, dan capek secara efektif (Hole dkk., 2015; Simaremare dkk., 2014; Simaremare, 2014) Tanaman ini sangat efektif karena memiliki senjata berupa rambut atau bulu-bulu kaku (trikoma) yaitu asam format yang dipercayai secara turun temurun jika ditempel pada bagian tubuh yang sakit, pegal, kaku, nyeri akan segera sembuh. Ketika trikoma dioleskan dalam tubuh, maka asam format akan keluar dari trikoma dengan proses enzimatis. Asam format akan memperlebar pori-pori darah sehingga darah lancaar mengalir dan mekanisme ini lah yang mengurangi rasa nyeri dan capek pada badan atau otot (Simaremare dkk., 2014; Simaremare dkk., 2015).

\footnotetext{
* Penulis Korespondensi. Email: eva smare@yahoo.com

Alamat : Perumahan Lumbung Berkat No. B3 Ekspo Jayapura Papua 99351
} 
Jurnal SEMAR Vol. 8 No. 2, 2019 hal. $10-16$

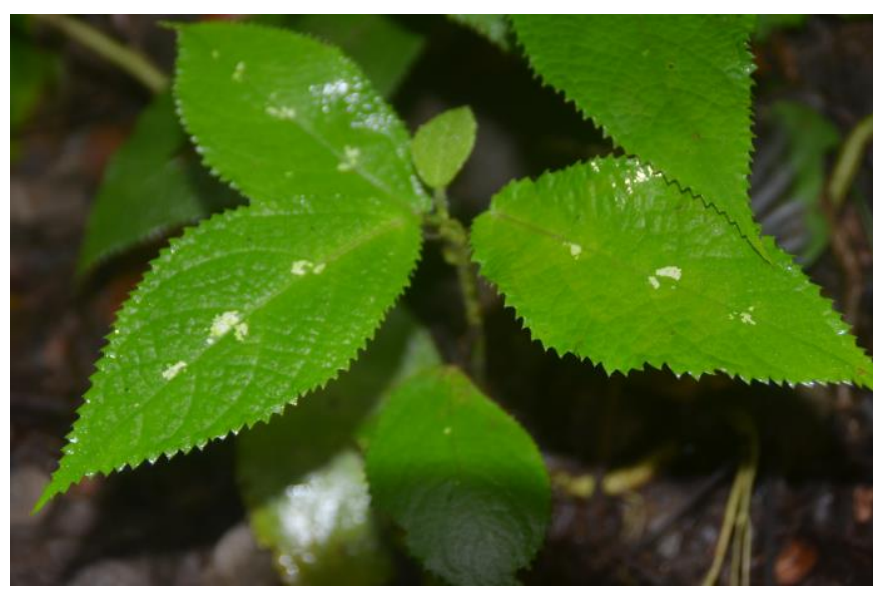

Gambar 1. Daun gatal

Beberapa masyarakat sangat percaya dan mempraktekkan pemakaian daun gatal untuk kesembuhan. Daun gatal tipe daun lebar digunakan dengan memukul mukul daun gatal pada bagian yang nyeri dengan tingkat kesakitan yang tinggi sedangkan daun gatal tipe daun kecil hanya diusap-usapkan pada bagian yang capek (Simaremare dkk., 2017). Daun ini sangat bermanfaat sekali untuk masyarakat di Papua khususnya masyarakat Arso.

Daun gatal dijual di pasar tradisional rakyat dengan mengambil lembaran daun gatal dan menyusunnya (sekitar 10 lembar) menjadi ikatan-ikatan kecil yang biasanya dijual seharga sepuluh ribu rupiah (Simaremare dkk., 2014) Para penjual daun gatal yang ada di pasar tradisional seperti pasar Youtefa berasal dari masyarakat Genyem (45,5 km dari kota Abepura, salah satu pusat aktivitas terbesar di Jayapura). Dari hasil survei di lapangan, para penjual hanya membawa 10-20 ikat daun gatal untuk dijajakan di pasar. Untuk mempertahankan kasiatnya perlu dibuat daun gatal kering supaya tidak busuk dan dapat bertahan lama (bulanan) yaitu dalam bentuk simplisia.

\section{Metode}

Pendekatan dilakukan melalui workshop dan sosialisasi serta pelatihan berupa penjelasan tujuan penerapan teknologi Farmasi bahan alam dalam meningkatkan nilai jual dari daun gatal. Pembuatan ini akan dibimbing oleh tim pelaksana dari staf Farmasi UNCEN dengan melibatkan mahasiswa dan masyarakat setempat.

\section{Lokasi dan waktu pengabdian}

Pengadian dilakukan di Kampung Arso XIV Kabupaten Kerom Jayapura Papua pada tanggal 11 Mei 2018.

\section{Metode dan tahapan dalam penerapan iptek}

Penelitian yang telah dikembangkan telah menghasilkan produk simplisia dan salep daun gatal. Metode yang dilakukan pada produk ini dibuat dengan mengambil daun dari pohonnya kemudian dikeringkan di bawah sinar matahari. Daun gatal dihaluskan dan dibuat menjadi simplisia. Simplisia diayak menjadi 25-75 $\mu \mathrm{m}$ dan dimasukkan dalam kemasan dan dipacking dengan baik. Setelah simplisia diperoleh kemudian diformulasi dengan bahan-bahan yang lain untuk menghasilkan produk daun gatal. 
Jurnal SEMAR Vol. 8 No. 2, 2019 hal. $10-16$

ISSN: 2302-3937 | Copyright (C) LPPM Universitas Sebelas Maret

Homepage: https://jurnal.uns.ac.id/jurnal-semar

\section{Formulasi salep daun gatal}

Simplisia dengan ukuran pori 175 dibuat salep basis larut air. PEG 4000 dileburkan terlebih dahulu sampai mencair kemudian ditambahkan dengan PEG 400 dan metil paraben. Setelah tercampur dengan sempurna, simplisia daun gatal dimasukkan dan dilanjutkan dengan minyak gandapura (Simaremare dkk., 2015; 2016; 2017)

\section{Evaluasi kegiatan}

Evaluasi kegiatan dilakukan dengan membuat instrumen berupa kuisoner. Setiap peserta akan dibagikan kuisoner dan diminta mengisi baik biodata, pemahaman atau pengetahuan tentang kegiatan yang dilakukan. Selanjutnya data disimpan dan dianalisis dan tingkat keberhasilan kegiatan dapat diukur. Evaluasi keberlanjutan program dilakukan pemantauan setelah kegiatan telah selesai dan masyarakat melakukan hasil kegiatan pengabdian ini.

\section{Hasil, Pembahasan dan Dampak}

\section{Persentasi peserta}

Kegiatan pengabdian ini telah dilakukan di Kampung Arso XIV Distrik Kerom Jayapura (Gambar 2). Kegiatan ini berlangsung 11 Mei 2018 dengan 83 orang masyarakat tetapi yang mengisi kuisoner hanya 27 orang.

Peserta yang mengikuti kegiatan ini dapat diklasifikasikan dari jenis kelamin, usia, pekerjaan, pendidikan, dan umur. Peserta yakni ada 19 orang perempuan dan 8 orang laki-laki dimana dari peserta perempuan dan laki-laki didominasi sebagai petani. Rentang usia peserta yang mengikuti pengabdian ini adalah usia 14-65 tahun seperti pada Tabel 2.

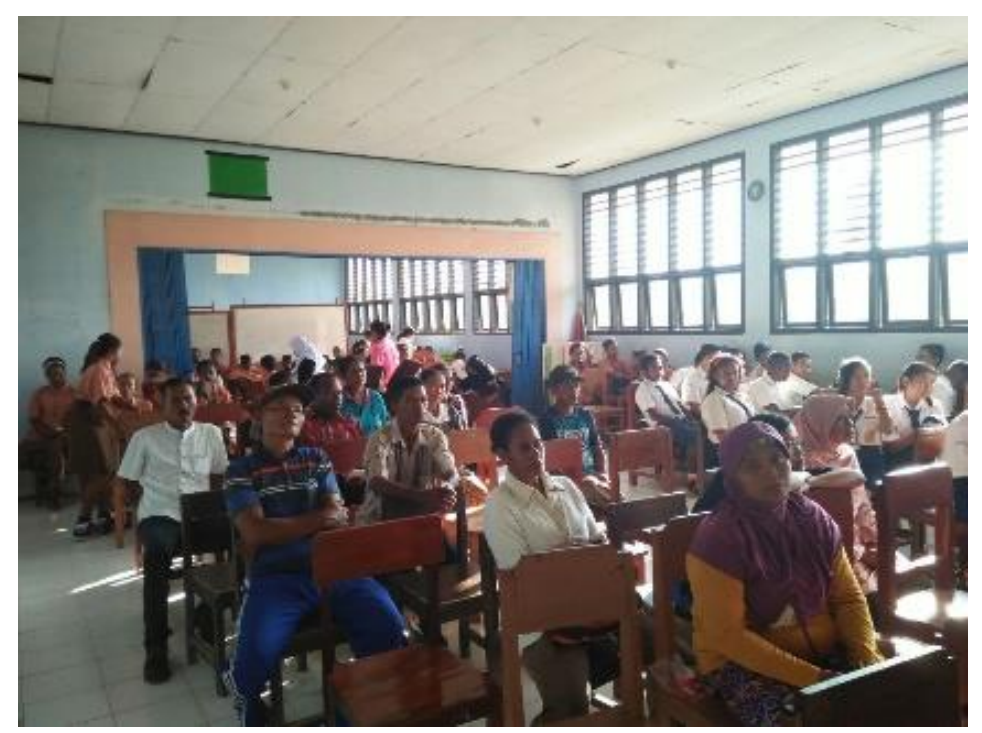

Gambar 2. Suasana kegiatan pengabdian pada masyarakat Arso XIV.

Dari data yang diperoleh bahwa masyarakat hanya 7,4\% mengikuti kegiatan seperti yang dilakukan tim Uncen tetapi itupun hanya kegiatan penyuluhan kesehatan biasa. Jadi kegiatan ini sangat bermanfaat bagi masyarakat dan diharapkan kegiatan ini dapat menjadi kegiatan rutin bagi 
Jurnal SEMAR Vol. 8 No. 2, 2019 hal. $10-16$

masyarakat dengan topik yang berbeda-beda tidak hanya tentang pemanfaatan daun gatal. Hasil persentase jumlah peserta yang pernah mengikuti kegiatan yang sama dapat dilihat pada Tabel 4.

Tabel 1. Persentase peserta dalam mengikuti kegiatan pengabdian pengenalan obat, swamedikasi

\begin{tabular}{ccc}
\hline Item & & $\begin{array}{c}\text { Persen } \\
\text { responden }\end{array}$ \\
\hline Tidak & 25 orang & $92,6 \%$ \\
Ya & 2 orang & $7,4 \%$ \\
\hline
\end{tabular}

Dari Tabel 2, daerah penduduk Arso didominasi dari penduduk pendatang lebih dari dua kali lipat dari penduduk asli. Daerah Arso memang banyak dihuni masyarakat transmigran karena perluasan daerah yang lebih banyak didominasi bekerja sebagai petani. Hasil pertanian Arso yang paling banyak yaitu sayur mayur, buah-buahan seperti jeruk, buah naga, semangka, dan lain-lain.

Tabel 2. Data peserta dalam kegiatan pengabdian pada masyarakat Arso XIV

\begin{tabular}{|c|c|c|}
\hline Jenis kelamin & \multicolumn{2}{|c|}{ Jumlah } \\
\hline Laki-laki & 8 & $30 \%$ \\
\hline Perempuan & 19 & $70 \%$ \\
\hline Jenis kelamin & \multicolumn{2}{|c|}{ Jumlah } \\
\hline Papua & 8 & $30 \%$ \\
\hline Maluku dan kepulauan & 2 & $7 \%$ \\
\hline Sulawesi & 5 & $19 \%$ \\
\hline Jawa & 10 & $37 \%$ \\
\hline NTT & 2 & $7 \%$ \\
\hline Usia & \multicolumn{2}{|c|}{ Jumlah } \\
\hline $10-20$ tahun & 8 & $30 \%$ \\
\hline 21-30 tahun & 2 & $7 \%$ \\
\hline $31-40$ & 5 & $19 \%$ \\
\hline $41-50$ & 10 & $37 \%$ \\
\hline $51-60$ & 1 & $4 \%$ \\
\hline$>60$ & 1 & $4 \%$ \\
\hline Pekerjaan & \multicolumn{2}{|c|}{ Jumlah } \\
\hline Pelajar & 8 & $30 \%$ \\
\hline PNS & 7 & $26 \%$ \\
\hline Swasta & 3 & $11 \%$ \\
\hline Petani & 9 & $33 \%$ \\
\hline
\end{tabular}

\section{Evaluasi data kuisoner peserta}

Masyarakat Arso XIV sudah mengenal banyak tanaman obat termasuk daun gatal (Tabel 3) sejak lama. Bahkan mereka menggunakan daun gatal ini setelah selesai bekerja di ladang atau baru pulang perjalan jauh. Dari data yang diperoleh, umumnya masyarakat yang menggunakan daun gatal sebagai obat tradisional adalah masyarakat Maluku dan Papua karena mereka sudah secara terun-temurun 
Jurnal SEMAR Vol. 8 No. 2, 2019 hal. $10-16$

menggunakan daun ini (Heyne, 1987; Tualeka, 1986). Sedangkan masyarakat lain lebih mengetahui dan belum menggunakan sebagai swamedikasi.

Tabel 3. Persentase tingkat pengetahuan masyarakat Arso XIV tentang daun gatal

\begin{tabular}{llcc}
\hline \multicolumn{1}{c}{ Jenis } & Jumlah & \multicolumn{2}{c}{ Persentase } \\
\hline \multirow{2}{*}{ Mengenal daun gatal } & Ya & 21 & $77,8 \%$ \\
& Tidak & 6 & $22,2 \%$ \\
\hline Menggunakan daun gatal & Ya & 23 & $85,2 \%$ \\
sebagai anti pegal & Tidak & 4 & $14,8 \%$ \\
\hline
\end{tabular}

Kegiatan pengabdian ini mendapat apresiasi dari masyarakat karena kampung jarang didatangi sosialisasi seperti pada kegiatan ini (Tabel 4). Pada kegiatan ini disampaikan tentang daun gatal, jenisjenis daun gatal, senyawa apa yang dapat menghilangkan nyeri pada trikoma daun gatal. Data-data hasil-hasil penelitian daun gatal yang sudah pernah dilakukan juga membantu masyarakat mengerti bahwa daun gatal secara ilmu pengetahun sudah diteliti [Simaremare dkk., 2016; Puro dan Yasni, 2012; Perdana dkk., 2016). Selanjutnya disampaikan aktivitas farmakologis apa saja yang potensial dari daun gatal seperti aktivitas analgesik, antiinflmasi (Simaremare et al., 2018), dan antikoagulan (pengumpalan darah).

Pada pemakaiaan yang lebih sederhana, kegiatan ini menawarkan bahwa daun gatal dapat digunakan dalam bentuk kering (bukan daun asli yang masih basah). Hal ini mempermudah masyarakat untuk menyimpan tanpa kuatir akan busuk. Pembuatan simplisia dilakukan dengan cara mengeringkan daun di udara terbuka (kira-kira 7 hari) atau menjemur di bawah sinar matahari (3-4 hari). Setelah kering daun dihaluskan, dikemas, dan dapat digunakan kapan saja.

Tabel 4. Persentase kemanfaatan kegiatan pengabdian pada masyarakat Arso XIV

\begin{tabular}{ccc}
\hline Kemanfaatan kegiatan & Jumlah & Persentase \\
\hline Tidak bermanfaat & 0 & $0,0 \%$ \\
Kurang bermanfaat & 0 & $0,0 \%$ \\
Cukup bermanfaat & 3 & $11,1 \%$ \\
Sangat bermanfaat & 24 & $88,9 \%$ \\
\hline
\end{tabular}

Pada kegiatan ini juga kami menyampaikan pembuatan pembuatan sedian topikal yaitu salep daun gatal. Pembuatan dilakukan dengan cara langsung mempraktekkan tahap demi tahap dari prosedur sehingga masyarakat mengerti cara melakukannya secara mandiri. Tetapi kendala yang muncul dari respon masyarakat adalah ketersediaan bahan baku yang masih awam buat masyarakat (sulit ditemukan) membuat mereka agak susah untuk memulai bisnis ini. Solusi yang ditawarkan adalah menjalin kerjasama dengan distributor yang sudah menjadi rekanan tim dan mulai mengurus ijin ke BPOM Jayapura. 


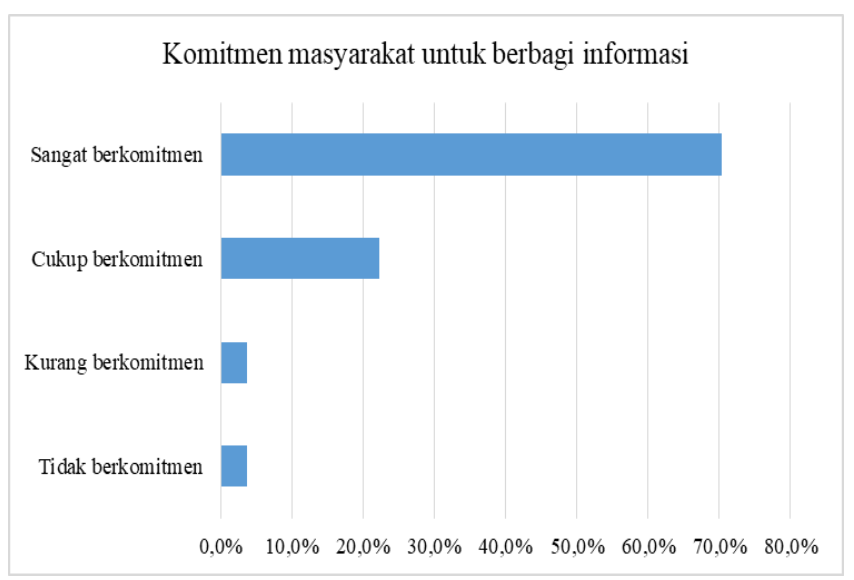

Gambar 3. Persentase komitmen masyarakat untuk berbagi informasi dengan orang lain.

Dari data analisis menjelaskan bahwa masyarakat sangat antusias dengan kegiatan ini. Hal ini dapat dilihat pada Gambar 3 bahwa masyarakat lebih dari 90\% sangat berkomitmen untuk berbagi informasi daun gatal dan pemanfaatannya terhadap orang lain di sekitar mereka.

\section{Penutup}

Dari hasil kegiatan pengabdian masyarakat ini hanya 7,4\% peserta pernah mengikuti kegiatan yang sama. Sebanyak $88,9 \%$ peserta memperoleh manfaat dari kegiatan ini dan $70,4 \%$ berkomitmen akan membantu orang lain dalam menyebarluaskan informasi penting yang mereka dapat pada waktu kegiatan ini.

\section{Ucapan Terima Kasih}

Ucapan terima kasih disampaikan kepada PNBP Universitas Cenderawasih, Jayapura Papua yang telah mendanai kegiatan ini dalam bentuk Hibah Pengabdian tahun 2018.

\section{Referensi}

Heyne, Karel, 1987. Tumbuhan Berguna Indonesia II. Jakarta. Badan Litbang Kehutanan.

Holle, Elizabeth, Eva Susanty Simaremare, I Made Budi, Yuliana Ruth Yabansabra, dan Elsye Gunawan, 2015. Evaluasi, Uji Aktivitas, dan Pengembangan Produk Salep Daun Gatal Papua Varietas Biak. Prosiding Seminar Nasional Biologi PBI ke-XXIII. Jayapura 8-9 September 2015.

Puro, Iman dan Yasni Sedarnawati, 2012. Kajian Aktivitas Antibakteri Daun Gatel (Laportea decumana (Roxb.) Wedd.) dan Daun Benalu Cengkeh. Skripsi. Institut Pertanian Bogor.

Perdana, Bayu Afnofandra, Andri Prima Putra, dan Angelia Primanisa, 2016. Uji Toksisitas Daun Jelatang ( Laportea sinuate Blume) terhadapa Larva Nyamuk Aedes aegipty. Universitas Andalas dalam https://anzdoc.com/uji-toksisitas-ekstrak-daun-jelatang.html. Diakses 27 Oktber 2018.

Simaremare, Eva Susanty, 2014. Skrining Fitokimia Ekstrak Etanol Daun Gatal (Laportea decumana (Roxb.) Wedd). Pharmacy. Vol 11, No 1, hal.98-107.

Simaremare, Eva Susanty, Agustina Ruban, Maria Taruli Nainggolan, Caroline Yenusi, Gloria Wabiser, dan Elsye Gunawan, 2014. Pemanfaatan Daun Gatal (Laportea Decumana (Roxb.) Wedd.) Varietas Biak Sebagai Antinyeri. Proseding Seminar Nasional Biologi. Vol 5, No 1, hal. 190-195.

Simaremare, Eva Susanty, Elizabeth Holle, Yuliana Ruth Yabansabra, I Made Budi, dan Elsye Gunawan, 2015. Analisis Perbandingan Efektifitas Antinyeri Salep Daun Gatal Dari Simplisia 
Jurnal SEMAR Vol. 8 No. 2, 2019 hal. $10-16$

ISSN: 2302-3937 | Copyright (C) LPPM Universitas Sebelas Maret

Homepage: https://jurnal.uns.ac.id/jurnal-semar

Laportea Aestuans (L) Chew dan Laportea Decumana (Roxb) Wedd. Pharmacy. Vol 12 (1):110.

Simaremare Eva Susanty, Yuliana Ruth Yabansabra, Elsye Gunawan, Agustina Ruban, 2016. Uji Mutu Fisik Sediaan Salep Daun Gatal (Laportea decumana (Roxb.) Wedd.) Sebagai Kandidat Antinyeri. Galenika. Vol 3, No 2, hal.55-60.

Simaremare, Eva Susanty, Agustina Ruban, dan Dirk Runtuboi, 2017. Aktivitas Antibakteri Ekstrak Etanol Daun Gatal (Laportea aestuans (L) Chew). Jurnal Biologi Papua. Vol 9, No 1, hal.1-7.

Simaremare, Eva Susanty, Elizabeth Holle, Elsye Gunawan, Yuliana Ruth Yabansabra, Fitri Octavia, and Rani Dewi Pratiwi, 2018. Toxicity, Antioxidant, Analgesic, and Anti-inflamantory of Ethanol Extract of Laportea aestuans (Linn.) Chew. Journal of Chemical and Pharmaceutical Research. Vol 10, No 5, hal. 16-23.

Tualeka, 1986. Pemeriksaan Farmakognostik dan Usaha Skrining Komponen secara Kromatografi Lapis Tipis daun gatal (Laportea decumana (roxb.) Wedd) asal Maluku. Skripsi. Universitas Hasanuddin.

\section{Biodata Peneliti}

\section{Eva Susanty Simaremare, M. Si}

Tenaga pendidik atau dosen pada program studi Farmasi FMIPA Universitas Cenderawasih Jayapura. Lahir di Tarutung Sumatera Utara 13 September 1983. Lulus Magister (S2) bidang Farmakokimia di Institut Teknologi Bandung pada tahun 2011. Saat ini menjabat sebagai Kepala Laboratorium Farmasi, Program Studi Farmasi FMIPA UNCEN. Pengalaman penelitian dan Pengabdian tiga tahun terakhir yaitu pengujian dan pemanfaatan daun gatal dan daun zodia asal Papua serta analisis Bahan Kimia Obat. 